\title{
The Economic Effects of Fulani Herdsmen and Farmers Crisis in Nigeria
}

\author{
Ogala, Sunday Christian \\ Department of Arts \& Humanities \\ School Of General Studies (GNS) \\ Delta State Polytechnic \\ Ogwashi - Uku, Delta State Nigeria. \\ E-mail: ogalasoc@yahoo.com, ogalasoc@gmail.com \\ Phone: 08063733887
}

\begin{abstract}
The study examined the economic effects of Fulani herdsmen and farmer conflicts in Nigeria using secondary data that covered nine state in Nigeria Adamawa, Benue, Delta, Edo, Enugu, Kogi, Oyo, Plataeu, and Taraba state. Efforts was made to examine the economic effects of Fulani herdsmen and farmers crisis on the Nigerian economy. The data comprises instances of 968 deaths that occurred between 2012 till date in the selected states. To establish the economic cost of the crisis, the expected income of the 968 persons who were killed during the crisis were calculated based on the assumptions that they died at age 30. Also, the expected human life insurance premium payable to insurance companies were calculated. The findings show that the country losses huge sum of money from the herdsmen and farmers crisis. This has a negative impact on the economy as the whooping sum of N464, $640,000.00$ is estimated to have been lost from the national savings in the short run during the period under review. This means that in the next 30 years (based on the assumed age of 30) the national economy would have lost about N4, 797,192,155.36. From the findings above it is clear that the herders-farmers crisis have enormous negative impact on the national economy. Based on the findings, the study recommended that government should take drastic steps to address the conflicts in order to reduce the economic consequences of the crisis on the economy.
\end{abstract}

Keywords: Economic Effects, Fulani Herdsmen and Farmers Crisis, Human Life Value.

Aims Research Journal Reference Format:

Ogala, Sunday Christian (2018): The Economic Effects of Fulani Herdsmen and Farmers Crisis in Nigeria.

Advances in Multidisciplinary \& Scientific Research Journal. Vol.4. No.1, Pp 101-112.

\section{INTRODUCTION}

Economic activities cannot thrive in the absence of relative peace and tranquility in any environment. Relative peace and favourable environment is precondition for production to take place. In recent times, there is an upsurge of violence in many states of the federation between the traditional Fulani herdsmen and peasant farmers in rural communities which has claimed thousands of lives alongside with destruction of properties. Like the devastating effects of the activities of the terrorist's group Boko Haram on the mostly affected states of Borno, Yobe and Adamawa which has crippled economic activities of those states during the peak of terrorist's insurgence this new spread of Fulani herdsmen attacking rural farmers poses a serious menace to internal peace and the agricultural sector of the Nigeria economy.

The raids by nomadic Fulani herdsmen are considered as the biggest security threat facing Nigeria after the Boko Haram insurgency. The herdsmen, mainly from the Fulani ethnic group, and farmers often clash for control of water and land (grazing territories). The Fula people also known as Fulani in Hausa language, are in mass population widely dispersed and culturally diverse in all of Africa, but most predominant in West Africa. A significant number of them are nomadic in nature, herding cattle, goats and sheep across the vast dry grass lands of their environment. They are massively spread over many countries, and are found mainly in West Africa and northern parts of Central Africa, but also in Sudan and Egypt. The main Fulani sub-groups in Nigeria are: Fulbe Adamawa, Fulbe Mbororo, Fulbe Sokoto, Fulbe Gombe, and the Fulbe Borgu (Eyekpimi, 2016). The modern Fulani are divided into nomadic pastoralists, semi -nomadic, and sedentary. They began cattle breeding since the $13^{\text {th }}$ to $14^{\text {th }}$ century (Doyin, Naij.com). The life of the Fulani herdsmen is nomadic in nature. From time immemorial, they have moved their cattle from one place to another searching for green pasture for them. The climatic condition of the northern part of the country, particularly in the North-east and North-west, has also forced the herders to move further south in search of grazing lands. 


\subsection{Objectives of the Study}

The aim of this study is to examine the economic effects of Fulani herdsmen and farmers crisis on the Nigerian economy. The specific objectives include to;

1. review the root causes of Fulani herdsmen and farmers crisis in Nigeria

2. examine the opportunity cost of loss of lives as a results of Fulani herdsmen and farmers crises in Nigeria

3. make recommendations on how to put an end to the Fulani herdsmen and farmers crises in Nigeria.

\subsection{Research Hypotheses}

The research hypotheses to be tested in this study is that:

There is no economic cost of loss of lives to the Nigerian economy as a result of the Fulani herdsmen and farmers crises. That is:

H0: $\quad$ There is no economic cost of loss of lives to the Nigerian economy as a result of the Fulani herdsmen and farmers crises

H1: There is economic cost of loss of lives to the Nigerian economy as a result of the Fulani herdsmen and farmers crises

\subsection{Significance of the Study}

This study is significant because its findings will inform the government and other stakeholders in the following ways:

1. Reveal the true causes of Fulani herdsmen and farmers crises in Nigeria which aid the government to put an end to the crises.

2. It will help to determine the real economic cost of loss of lives and its opportunity cost on the economy

3. It will contribute to the existing literature on crisis between Fulani herdsmen and farmers in Nigeria.

\section{REVIEW OF RELATED LITERATURE}

The herders - farmers' conflicts have actually drawn the attention of many scholars in the literature. Many publications have been made on the causes, effects and suggested solutions to the crises in the literature. However, there is no general consensus on the subject. In this study, effort is made to give a brief review of the literature of herdsmen and farmers crises in Nigeria.

\subsection{Causes of Fulani Herdsmen and Farmers Crises in Nigeria}

Among the principal causes and aggravating factors behind this escalating conflict between Fulani herdsmen and farmers are climatic changes (frequent droughts and desertification); population growth (loss of northern grazing lands to the expansion of human settlements); technological and economic changes (new livestock and farming practices); crime (rural banditry and cattle rustling); Boko Haram insurgency (intensified by the spread of illicit firearms); and cultural changes (the collapse of traditional conflict management mechanisms). A dysfunctional legal regime that allows crime to go unpunished has encouraged both farmers and pastoralists to take matters into their own hands.

\section{Climate Change (Droughts and Desertification) in the North}

Nigeria's far north is arid and semi-arid, with a long dry season from October to May and low rainfall from June to September. In the last six decades, over $350,000 \mathrm{sq} \mathrm{km}$ of the already arid region turned to desert or desert-like conditions, a phenomenon progressing southward at the rate of $0.6 \mathrm{~km}$ per year (Federal Ministry of Environment, National Policy on Desertification and Drought, 2008). In Bauchi, Borno, Gombe, Jigawa, Kano, Katsina, Kebbi, Sokoto, Yobe and Zamfara states, estimates suggest that 50-75 per cent of the land area is becoming desert. (FAO Country Programming Framework (CPF) Federal Republic of Nigeria 2013-2017, op. cit., p. 6.) These environmental changes have wrecked agriculture and human livelihoods, forcing millions of pastoralists and others to migrate south, in search of productive land (Crisis Group Interview Report, 2017).

\section{Loss of Grazing Reserves}

Most of the 415 grazing reserves established by the northern regional government in the 1960s have since been lost. Only 114 were formally documented or demarcated, though the government failed to back these agreements with legislation guaranteeing exclusive usage or take active measures to prevent encroachment (Crisis Group Interview Report, 2017). The rest were lost to pressure associated with the demand for farmland because of population expansion coupled with the disintegration of the northern region into nineteen (19) states. 


\subsection{Effects of Fulani Herdsmen and Farmers Crises on the Economy.}

Among others some the effects of the Fulani herdsmen and farmers crises are briefly discussed below.

\section{Loss of private Investments}

The Fulani herdsmen and farmers crises has led to the huge loss of private investments in the affected states. For example the ethnic Nzor-Tiv Global Association estimated its Agatu communities in Benue state lost N65 billion in property (\$204 million) during the early 2016 herder attacks (Edward, 2016). This is the value for Benue State alone, who of other affected states like Kaduna, Nasarawa, Plateau, Enugu to mention a few where the exact worth lost private investments by individuals are not available.

\section{Socio-Economic Stagnation:}

For communities that are affected by Fulani herdsmen attacks in the affected states, social and economic activities are usually paralyzed during the period of crises for instance schools will shut down and pupils withdrawn, businesses were shut down and economic movement in the region became extremely difficult. The violence has stagnated socio-economic activities because peace is paramount to economic growth.

\section{Economic Difficulties via Social Tension:}

The Fulani herdsmen and farmers crises has through Violence breeds tension in the society. Fear of attacks and reprisal attacks creates tension which tends to slow down economic activities.

\section{Unemployment Problems.}

The Fulani herdsmen and farmers crises has without doubt helped in worsening the unemployment situation in the country through the loss of private investments and displacement of individuals. Those who lose their businesses because of the crises automatically become unemployed thereby compounding the unemployment situation in the country.

\section{Heightening the problem of food insecurity}

Nigeria as a nation is seriously faced with the problem of food insecurity due to under-utilization of its agricultural potentials. Even though a bulk of her populations are engaged in agriculture yet the country still depend on food imported from Europe and America. The farmers' herdsmen crises through the destruction of arable lands, food and cash crops has reduced the availability of produce for sales thereby heightening the problem of food insecurity.

\subsection{Empirical Review of Fulani Herdsmen and Farmers Conflicts}

The spreading Fulani herdsmen and farmers crises across the country has attracted and is attracting academic scholars on the subject. Sulaiman and Ja'afar-Furo (2010) in a study of the Economic Effects of Farmer-grazier Conflicts in Nigeria A Case Study of Bauchi State observed that the conflicts have had negative economic effects on both the families involved and the nation in terms of the huge resources lost. They strongly recommended that the government should put appropriate measures towards curbing the occurrence of such conflicts for the benefit of all. In a comprehensive study of Herders and Farmers crises in Nigeria by International Crisis Group (ICG) (2017) it was discovered that the escalating conflicts between herders and farmers are among Nigeria's most pressing security challenges. They opine that the crises could potentially generate bloodshed on an even wider scale unless President Buhari's government makes ending this violence a national priority. They added that State governments also need to formulate and implement steps to address the needs and grievances of all sides transparently and equitably by strengthening law enforcement, supporting local conflict prevention and resolution mechanisms, and that establishing and protecting grazing reserves would make a significant and immediate difference. They concluded that in the longer term, the greater challenge will be curbing the arms influx and, crucially, addressing the environmental trends that are forcing herders south as Failure would spell greater danger for a country already battling other severe security challenges.

Dimelu et al (2017) in a study of the Challenges of herdsmen-farmers' conflict in livestock production in Nigeria: Experience of pastoralists in Kogi State, Nigeria observed that Conflicts between pastoralists and crop farmers were caused by socio-economic, security, production practices and institution related factors adding that pastoralists had the problems of insecurity of human and animal lives, displacement and economic losses leading to poor productivity. They recommend that all stakeholders (government, non-governmental organizations, extension agencies, rural institutions among others) should intensify efforts to build cooperative and peaceful coexistence between farmers and pastoralists through public enlightenment, education and campaign in agrarian communities. They concluded that Government and NGOs should promptly intervene with aids/compensation to reduce vulnerability, persistence and further spread of conflict of pastoralist-farmer conflict in communities. Also, Odoh and Chilaka (2012) in a study of climate change and conflict in Nigeria: a theoretical and empirical examination of the worsening incidence of conflict between Fulani herdsmen and farmers in Northern Nigeria argued that the remote cause of the conflicts is climate change which has through drought and desertification led to the worsening incidence of natural resource scarcity 
They suggested that since climate change has come to stay the government to put more machinery on ground particularly in the north because over 70 percent of the nation's food crop comes from the region by encouraging climate change mitigation and adaptation. They finally recommended that climatologic research should be enhanced to combat desert encroachment, and in the long run reduce inherent conflicts. In another study of Causes, Effects and Resolution of Farmers-Nomadic Cattle Herders Conflict In Delta State, Nigeria the by Albert Ofuoku (2010) he observed that the causes of such conflicts were destruction of crops, contamination of streams by cattle, zero grazing of land, disregard for local traditional authorities, female harassment, harassment of nomads by host community youths, indiscriminate bush burning, defecation of cattle on roads, cattle theft and straying of cattle. He further added that the socio-economic effects of the conflicts result to reduction in crop yield and income of farmers/nomads displacement of farmers, loss of lives and properties and loss of products in the storage.

Alhassan Bello (2013) in a study of Herdsmen and Farmers Conflicts in North-Eastern Nigeria: Causes, Repercussions and Resolutions find that the conflicts have demonstrated high potential to exacerbate the insecurity and food crisis particularly in rural communities where most of the conflicts are localized, with reverberating repercussions nationwide. He concluded that there is the need to identify the causes, repercussions and proffered resolution of the critical issues that are at the roots of the conflicts. Also, in another study by Ibrahim et al (2015) in an assessment of farmer-pastoralist conflict in Nigeria using GIS identified increase in population, drying of waterholes, shifting in rainfall pattern leading to drought as a result of the changing climate affects both pastoralists and farmers. Hence, they compete over land leading to conflict, and embedded within these are growing form of capitalists land tenure and delay in the justice system that exacerbates the situation. They proposed a possible revisit of symbiotic engagements between farmers and pastoralists and suggested that full engagement of communities, Non-governmental Organizations (NGOs), Alternative Dispute Resolutions (ADRs) be employed.

From the empirical review, no previous study has been able to determine the economic value or cost of lost lives to the national economy as a result of herders-farmers crisis. It is this gap that this tends to fill.

\subsection{Theoretical Framework}

A conscious effort will be made to adopt a theoretical framework that will best explain and guide us in understanding the economic effects of herdsmen and farmers crisis in Nigeria. In its general use the term economic effects means aftermath economic consequences on both individuals and households at the microeconomic level and the economy as a whole at the macroeconomic level. From the review of the causes of herders and farmers crises or conflicts we can presume that the principal cause of the crisis is climate change which has affected the availability of arable land for farming and grazing reserves for herders.

\section{Homer-Dixon Eco - Violence Theory}

Homer-Dixon articulated the theory of eco-violence which argued that large populations in many developing countries are highly dependent on four key environmental resources that are very fundamental to crop production: fresh water, cropland, forests and fish and that Scarcity or shrinking of these resources as a result of misuse, over-use or degradation under certain circumstances will trigger off conflicts (Odoh and Chilaka, 2012). The fundamental theoretical assumption of the Homer-Dixon theory is that resource scarcity is the product of an insufficient supply, too much demand or an unequal distribution of a resource as a result of environmental hazards that forces some sector of a society into a condition of deprivation and violence. These four sources of scarcity are in turn caused by variables such as population growth, economic development, pollution and obviously climate change. Thus, environmental resource scarcity will constrain agricultural and economic productivity, further inducing the disruption of economic livelihoods, poverty and migration. Migration can occur either because the environmental quality of a habitat has become unlivable or, more commonly, because the migrant's economic outcome is likely to be better in areas with greater resource availability. Both constrained productivity and migration are likely to strengthen the segmentation around already existing religious, class, ethnic or linguistic cleavages in a society18 and thus precipitate conflicts (Odoh and Chilaka, 2012).

Conflict which is seen by Hocker Wilmot (1985) as the interaction of independent people who perceive incompatible goals and interference from each other in achieving goals. Thus both parties (herdsmen and farmers) perceive conflicting views which eventually induce one of the parties to always seek redress against existing contradictions (Ofuoku and Isife 2010). On the other hand, these crisis has led to destruction of property, human displacement and loss of human lives (human capital) with its attendant economic consequences on the economy. The main objective of this study is to examine the opportunity cost of lost lives as a results of Fulani herdsmen and farmers crises to the economy using Human Life Value (HLV) as proxy. Therefore the theoretical framework tend to synthesis the theory of human capital with that of eco-violence theory of Homer-Dixon examining the economic effects of herdsmen and farmers crisis in Nigeria. 


\section{The Economic Value of Human Life}

Putting a price on human life may seem callous, but for safety analysts, it's simply necessary. The human life value concept deals with human capital, which is a person's income potential. It goes beyond just the numbers and considers the overall impact of losing someone, especially the breadwinner (Tony Steur, 2018).

It was developed by Dr. Solomon S. Heubner in 1924 by pointing out that the economic value of human life can be expressed in monetary terms by discounting estimated future net earnings used for family purposes at a reasonable rate of interest. The way of calculating your human life value is to multiply your current or prospective income with a factor between 6 and 10 depending upon your age. This is the economic value of an individual to his or her family. This is the amount of life insurance you ideally need to cover the risk of premature death (Archana, 2014).

\section{The Concept of Annuity}

An annuity is a contractual financial product sold by financial institutions that is designed to accept and grow funds from an individual and then, upon annuitization, pay out a stream of payments to the individual at a later point in time. The period of time when an annuity is being funded and before payouts begin is referred to as the accumulation phase. Once payments commence, the contract is in the annuitization phase (Investopedia, 2018).

\section{Types of Annuities}

Annuities can be structured according to a wide array of details and factors, such as the duration of time that payments from the annuity can be guaranteed to continue. Annuities can be created so that, upon annuitization, payments will continue so long as either the annuitant or their spouse (if survivorship benefit is elected) is alive. Alternatively, annuities can be structured to pay out funds for a fixed amount of time, such as 20 years, regardless of how long the annuitant lives. Furthermore, annuities can begin immediately upon deposit of a lump sum, or they can be structured as deferred benefits. Annuities can be structured generally as either fixed or variable. Fixed annuities provide regular periodic payments to the annuitant. Variable annuities allow the owner to receive greater future cash flows if investments of the annuity fund do well and smaller payments if its investments do poorly. This provides for a less stable cash flow than a fixed annuity, but allows the annuitant to reap the benefits of strong returns from their fund's investments.

\section{Annuity Formula}

$$
P=\frac{A\left[(1+r / 100)^{n}-1\right]}{(1+r / 100)-1}
$$

Where:

$P=$ present value

$A=$ amount invested

$\mathrm{n}=$ number of year

$r=$ rate of interest

It is fundamental to state that one basic feature of Fulani herdsmen is migration and at the heart of migration is climate change. Within the context of Fulani herdsmen and farmer conflict, the eco-violence theory is analytically fecund to capture, and explicate the intricate linkages that can develop between climate change and conflict (Odoh and Chilaka, 2012).

Also, the reverberating effects of the Fulani herdsmen and farmers crisis is huge economic losses to the economy especially the loss of human lives with estimated death toll of approximately 2,500 people in 2016 (ICG Report, 2017). While the eco - violence theory is analytical fruitful in pointing out the root cause of the conflict, the human life value theory also fecund to capture the economic loss of human lives (human capital) resulting from the Fulani herdsmen and farmers crises in Nigeria. 


\section{RESEARCH METHOD}

This study employ the descriptive research approach using secondary data obtained from newspaper publications from 2012 till date on the affected states, the local government area, the affected community, the period or date of conflicts and the number of lives lost.

Table 1: Number of persons killed by Fulani herdsmen arising from their conflicts with farmers across various states in Nigeria from 2012 to date.

\begin{tabular}{|c|c|c|c|c|}
\hline State & Local Govt. Area & Community & Date of Event & Number of Lost Lives \\
\hline Plateau & Riyom LGA & Maseh & Jul-12 & 52 \\
\hline Benue & Guma LGA & Mbasenge & April 23, 2013 & 10 \\
\hline Benue & Agatu LGA & Agatu & May 7, 2013 & 47 \\
\hline Benue & Agatu LGA & Ekwo-Okpanchenyi & May 14,2013 & 40 \\
\hline Benue & Guma LGA. & Nzorov & July 5, 2013 & 20 \\
\hline Benue & Agatu LGA & Agatu & July 28,2013 & 8 \\
\hline Benue & Agatu LGA & Ikpele \& Okpopolo & November 7, 2013 & 7 \\
\hline Benue & Agatu LGA & 7 Villages & November 9, 2013 & 36 \\
\hline Plateau & & Ninji and Ropp villages & Jun-15 & 87 \\
\hline Delta & Ndokwa West LGA & Onitsha Ukwuani & Sep-15 & 3 \\
\hline Edo & & & Sep-15 & 1 \\
\hline Kogi & Dekina LGA & Ulaja and Ojeh & Nov-15 & 22 \\
\hline Delta & Isoko North LGA & Ofagbe & December 1, 2015 & 1 \\
\hline Benue & Buruku LGA & $\begin{array}{l}\text { Tom-Anyiin, } \\
\text { Mbaya and Tombu }\end{array}$ & February 8, 2016 & 10 \\
\hline Enugu & Uzo-Uwani LGA & Abbi & February 11, 2016 & 2 \\
\hline Benue & Agatu & & February 29, 2016 & 500 \\
\hline Benue & Logo LGA & $\begin{array}{l}\text { Ngorukgan, Tse Chia, Deghkia } \\
\text { and Nhumbe }\end{array}$ & March 9, 2016 & 8 \\
\hline Benue & & & April 5, 2016 & 4 \\
\hline Edo & & & April 92016 & 1 \\
\hline Taraba & & Dori and Mesuma & April 12, 2016 & 15 \\
\hline Oyo & Lagelu LGA & Lagun & April 19, 2016 & 1 \\
\hline Enugu & & Ukpabi Nimbo & April 25, 2016 & 48 \\
\hline Adamawa & Girei LGA & & June 24,2016 & 30 \\
\hline Benue & Logo LGA & $\begin{array}{l}\text { Tse Akombo, Tse Vii and Tse } \\
\text { Agule }\end{array}$ & January 6, 2018 & 15 \\
\hline TOTAL & & & & 968 \\
\hline
\end{tabular}

Sources: Table Compiled by Author.

Guardian Newspaper Publication Apr $29^{\text {th }} 2016$ by the Editor at https://guardian.ng/features/killings-carried-out-bysuspected-herdsmen-between-2012-and-2016-according-to-the-media-reports/

Premium times publication January $24^{\text {th }} 2016$ by Austin Ajayi at https://www.premiumtimesng.com/news/headlines/197299-nigeria-police-dpo-29-others-killed-in-herdsmen-vsfarmers-clash.html

Vangaurd Newspaper Publications Janauary $6^{\text {th }} 2018$ by Peter Duru at https://www.vanguardngr.com/2018/01/village-head-15-others-killed-fresh-herdsmen-attack-benue-communities/ 


\subsection{Methods of Data Collection}

The data for this study was obtained from secondary sources only, specifically, it was collected from newspaper publications of lost lives arising from Fulani herdsmen and farmers crisis across the country since 2012 till date. The study adopted the Human Life Value (HLV) approach in estimating life insurance need (that is the required life insurance need those who lost their lives would have paid if there were to live till their retirement age) to the analysis of losses of human lives because of the Fulani herdsmen and farmer's conflicts in Nigeria from 2012 till date with some underlying assumptions:

1. That the 968 individuals (sample size) who lost their lives are still within their working live with an assumed age of 30 years implying that they would have still worked for 30 years

2. That the 968 individuals earn or generate a minimum revenue of $\mathrm{N} 18,000$ monthly from their farming activities and other engagements, that is, each has annual income of N216,000

3. That the 968 individuals at least spend N10,000 of their monthly revenue to maintain their family living expenses, that is, each has annual living expenses of $\mathrm{N} 120,000$

4. That the 968 individuals have monthly savings of $N 8,000$ that is, each have an annual savings of $N 96,000$

5. That the 968 individuals are entitled to at least $3.5 \%$ future increases in their income before the attainment of their retirement age.

6. A constant discount factor interest rate of $5 \%$ throughout their working life till retirement.

7. That the 968 individuals have a life insurance policy that was to run till retirement.

Economic research related to investment in human capital for example the Human Life Value (HLV) has gained substantial recognition. For instance, the 1992 Nobel Prize for Economics was awarded to Professor Gary S. Becker for his pioneering research on human capital (Huebner and Kenneth, 1976). It is now believed that "the value of an item must not be based on its price but rather on the utility that it yields" (Daniel, 1964). Today, the idea of human capital is construed as the sum of natural talent, education, training, and experience that comprise the 'wellspring of future earnings flows', and is viewed "as fundamental to the understanding of major shifts in the global economy."Peter. L. (1996). 


\section{ANALYSIS AND FINDINGS}

By interpolation, using Microsoft excel result based on the above parameters the HLV (the sum of money that when paid in instalments of both principal and interest over the individual remaining working life, will produce the same income the person would have earned, minus taxes and personal expenses) a single individual is shown below.

Table 2: Human Life Value Approach to Calculating an Insurance Need

\begin{tabular}{|c|c|c|c|c|}
\hline \multicolumn{5}{|c|}{ Human Life Value Approach to Calculating an Insurance Need } \\
\hline \multicolumn{5}{|c|}{ Assumptions: } \\
\hline \multicolumn{4}{|c|}{ Age at Time of Insurance Purchase: } & 30 \\
\hline \multicolumn{4}{|c|}{ Initial Income: } & 18000 \\
\hline \multicolumn{4}{|c|}{ Number of Years of Working Life: } & 30 \\
\hline \multicolumn{4}{|c|}{ Assume that Income Increases each year: } & $3.50 \%$ \\
\hline \multicolumn{4}{|c|}{ Discount Rate of Interest [Int.] $=$} & $5 \%$ \\
\hline Age & Duration & Income & Interest Rate & Present Value \\
\hline 30 & 1 & $18,000.00$ & 0.95238 & $17,142.86$ \\
\hline 31 & 2 & $18,630.00$ & 0.90703 & $16,897.96$ \\
\hline 32 & 3 & $19,282.05$ & 0.86384 & $16,656.56$ \\
\hline 33 & 4 & $19,956.92$ & 0.82270 & $16,418.61$ \\
\hline 34 & 5 & $20,655.41$ & 0.78353 & $16,184.06$ \\
\hline 35 & 6 & $21,378.35$ & 0.74622 & $15,952.86$ \\
\hline 36 & 7 & $22,126.60$ & 0.71068 & $15,724.96$ \\
\hline 37 & 8 & $22,901.03$ & 0.67684 & $15,500.32$ \\
\hline 38 & 9 & $23,702.56$ & 0.64461 & $15,278.88$ \\
\hline 39 & 10 & $24,532.15$ & 0.61391 & $15,060.61$ \\
\hline 40 & 11 & $25,390.78$ & 0.58468 & $14,845.46$ \\
\hline 41 & 12 & $26,279.45$ & 0.55684 & $14,633.38$ \\
\hline 42 & 13 & $27,199.24$ & 0.53032 & $14,424.34$ \\
\hline 43 & 14 & $28,151.21$ & 0.50507 & $14,218.27$ \\
\hline 44 & 15 & $29,136.50$ & 0.48102 & $14,015.16$ \\
\hline 45 & 16 & $30,156.28$ & 0.45811 & $13,814.94$ \\
\hline 46 & 17 & $31,211.75$ & 0.43630 & $13,617.58$ \\
\hline 47 & 18 & $32,304.16$ & 0.41552 & $13,423.05$ \\
\hline 48 & 19 & $33,434.81$ & 0.39573 & $13,231.29$ \\
\hline 49 & 20 & $34,605.02$ & 0.37689 & $13,042.27$ \\
\hline 50 & 21 & $35,816.20$ & 0.35894 & $12,855.95$ \\
\hline 51 & 22 & $37,069.77$ & 0.34185 & $12,672.29$ \\
\hline 52 & 23 & $38,367.21$ & 0.32557 & $12,491.26$ \\
\hline 53 & 24 & $39,710.06$ & 0.31007 & $12,312.82$ \\
\hline 54 & 25 & $41,099.91$ & 0.29530 & $12,136.92$ \\
\hline 55 & 26 & $42,538.41$ & 0.28124 & $11,963.53$ \\
\hline 56 & 27 & $44,027.25$ & 0.26785 & $11,792.63$ \\
\hline 57 & 28 & $45,568.21$ & 0.25509 & $11,624.16$ \\
\hline 58 & 29 & $47,163.10$ & 0.24295 & $11,458.10$ \\
\hline 59 & 30 & $48,813.80$ & 0.23138 & $11,294.41$ \\
\hline 60 & 31 & $50,522.29$ & 0.22036 & $11,133.06$ \\
\hline ESTIM & LIFE INSUF & כ FOR AN & & $431,818.55$ \\
\hline
\end{tabular}

Source: Author's Calculation using excel.

From the result above the human life value life insurance premium needed for an individual given the assumed parameters is N431, 818.55. Thus, for the 968 individuals who lost their lives the cumulative HLV life insurance premium that would have been paid is $\mathrm{N} 431,818.55 \times 968=\mathrm{N} 418,000,356.4$. We can infer from this result that over the next 30 years, the insurance industry will lose about $\mathrm{N} 418,000,356.4$ worth of premium. We can estimate the gross loss in the national savings by estimating the annuity of the savings that would have been made by those who lost their lives to the crisis. Following our no 4 assumption that each of the 968 persons have an annual savings of N96, 000. Assume interest rate is $3.5 \%$ for 30 years. 


$$
P=\frac{A\left[(1+r / 100)^{n}-1\right]}{\left(1+\frac{r}{r} / 100\right)-1}
$$

Where:

$\mathrm{P}=$ present value?

$A=$ amount invested $=96,000$

$\mathrm{n}=$ number of year $=30$

$r=$ rate of interest $=3.5 \%$

$$
\begin{array}{ll}
P=\frac{96,000\left[\left(1+{ }^{3.5} / 100\right)^{30}-1\right]}{\left(1+{ }^{3.5} / 100\right)-1} & =\frac{96,000\left[(1.035)^{30}-1\right]}{0.035} \\
P=96,000[2.806793705-1] & =\frac{96,000 \times 1.806793705}{0.035}
\end{array}
$$

$$
P=\frac{173452.1957}{0.035} \quad=\quad N 4,955,777.02
$$

$$
0.035
$$

In the long run, an individual will accumulate an annuity of about N4,955,777.02 to the national savings in the next 30 years if he were to be alive. Accordingly, the 968 individuals in the long run would have contributed $968 \times \mathrm{N} 4$, $955,777.02=$ N4, 797,192,154.02. Hence, in the long run, the Nigerian economy will lose about N4, 797,192,154.02 from the national savings in the next 30 years because of the Fulani herdsmen and farmers conflict. On the other hand, in the short run the estimated loss from the national savings can be expressed as $96,000 \times 5$ (where 5 is years difference from $2012-2017$ ) that is, $\mathrm{N} 480,000.00$. Thus, from 2012 to 2017 the Nigerian economy has lost about $\mathrm{N}$ $464,640,000.00$.

\section{Descriptive Statistics Result.}

\begin{tabular}{|l|l|}
\hline STATE & NO. OF LOST LIVES \\
\hline ADAMAWA & 30 \\
\hline BENUE & 705 \\
\hline DELTA & 4 \\
\hline EDO & 2 \\
\hline ENUGU & 50 \\
\hline KOGI & 22 \\
\hline OYO & 1 \\
\hline PLATEAU & 139 \\
\hline TARABA & 15 \\
\hline TOTAL & 968 \\
\hline
\end{tabular}

\begin{tabular}{|l|l|l|l|}
\hline No. of Lost Lives & & Estimated Annual Min. Wage Loss & \\
\hline \hline Mean & 484.5 & Mean & $\mathbf{2 1 6 0 0 0}$ \\
\hline Standard Error & 8.986100378 & Standard Error & 0 \\
\hline Median & 484.5 & Median & 216000 \\
\hline Mode & \#N/A & Mode & 216000 \\
\hline Standard Deviation & 279.5818306 & Standard Deviation & 0 \\
\hline Sample Variance & 78166 & Sample Variance & 0 \\
\hline Kurtosis & -1.2 & Kurtosis & \#DIV/0! \\
\hline Skewness & $5.52234 \mathrm{E}-17$ & Skewness & \#DIV/0! \\
\hline Range & 967 & Range & 0 \\
\hline Minimum & 1 & Minimum & 216000 \\
\hline Maximum & 968 & Maximum & 216000 \\
\hline Sum & 468996 & Sum & 209088000 \\
\hline Count & 968 & Count & 968 \\
\hline Confidence Level(95.0\%) & 17.6345052 & Confidence Level(95.0\%) & 0 \\
\hline
\end{tabular}




\subsection{Test of Hypotheses}

H0: $\quad$ There is no economic cost of loss of lives to the Nigerian economy as a result of the Fulani herdsmen and farmer's crises implying that the mean value of the estimated annual minimum wage loss is zero $(\mathrm{H} 0=0)$

H1: There is economic cost of loss of lives to the Nigerian economy as a result of the Fulani herdsmen and farmer's crises implying that the mean value of the estimated annual minimum wage loss is greater than zero $(\mathrm{H} 1 \neq 0)$

Accordingly we test the null hypotheses using test of means for the sample of lost lives.

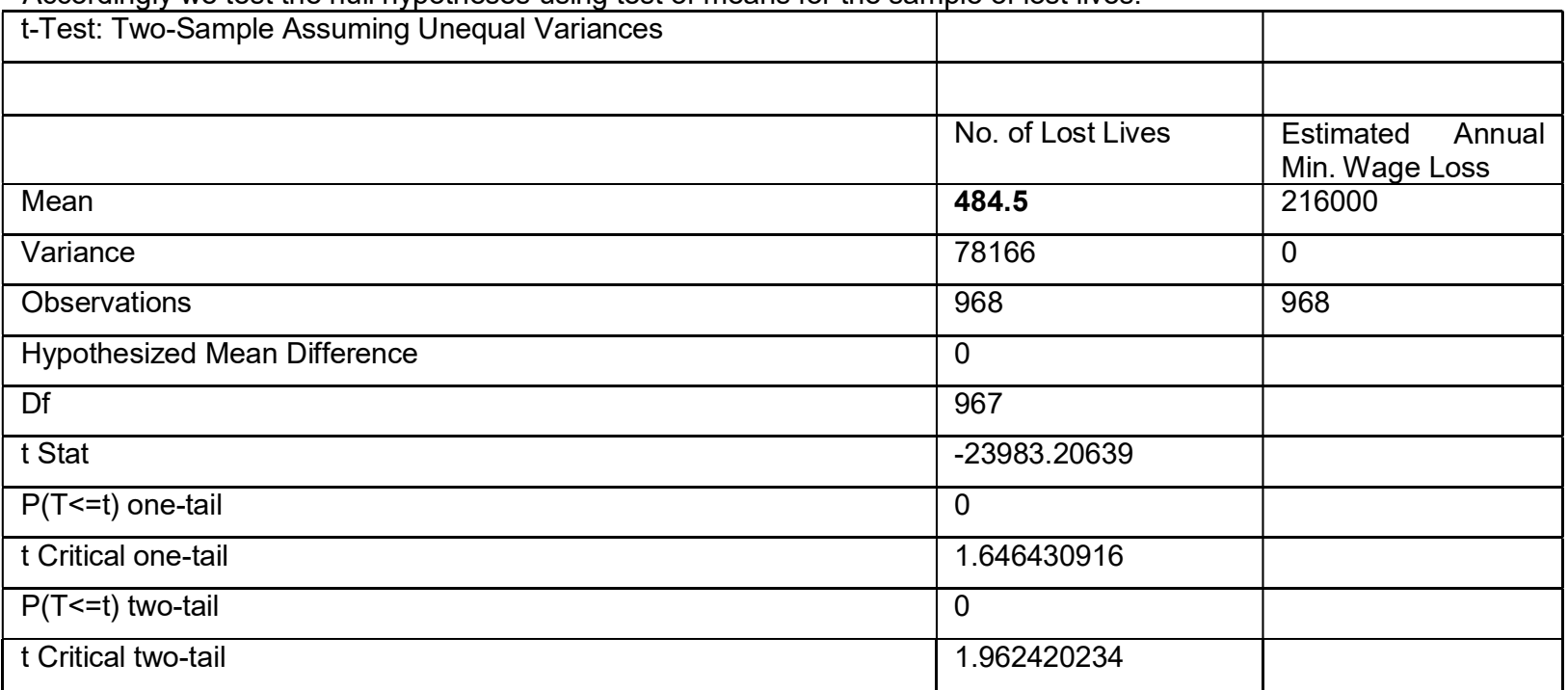

Source: Computed by Author using excel

Computed $\mathrm{t}-$ statistic $=-23983.20639$

Critical t statistics $=1.646430916$

\section{Decision Rule.}

Accept the null hypothesis when the computed $t$ - value is less than the critical $t$ - value and reject otherwise.

From the computed $t-23983.20639$ is less than the critical $t$ value 1.646430916 which implies that we accept the null hypothesis and reject the alternate hypothesis. However, caution should be applied in drawing our conclusion.

\section{CONCLUSION}

The study has made efforts to examine the economic effects of Fulani herdsmen and farmers crisis on the Nigerian economy. By and large, the causes driving the conflicts were reviewed and it was discovered that one of the main factors propelling the crisis is climate change resulting in scarcity of resource availability for herders and farmers. This conflict of interest in the absence of effective negotiation mechanism results in violent crises between Fulani herdsmen and farmers. Unfortunately, this conflicts has led to destruction of properties worth several millions of naira, displaced thousands of persons making them economically handicapped, enhanced economic stagnation of the affected communities and states and loss of thousands of lives.

Measuring the economic value of human life in the absence of reliable economic data and human capital indices in Nigeria is a very difficult task yet, the opportunity cost of the economic value of lost lives arising from the herders and farmers crisis is huge. The loss of human lives implies the loss of entrepreneurs, the loss of productive capabilities, and the loss of savings. These losses represent huge opportunity cost to the national economy 


\section{RECOMMENDATION}

Thus far, the study has revealed the importance of human life value and human capital to the economic development of the nation. Based on the review of the causes and effects of the Fulani herdsmen and farmers crises the following recommendations is made:

1. The federal and state government should intensify the efforts to control desertification and other environmental hazards that is propelling the crisis.

2. The state government should enact appropriate grazing laws that will define the limit of Fulani herdsmen activities because by their uncontrolled and night grazing do infringe on farmers right to food.

3. The state government should establish conflict management board that is tasked with the responsibility of addressing grievances of herders and farmers.

4. The federal government should make efforts to harmonize the recommendations of the academia on addressing herders and farmers' crisis.

5. Finally, the federal judicial system should review their judicial process that is effective in implementing the rule of law.

\section{REFERENCE}

1. Adedoyin Adewumi (2016): Economic Havocs of Fulani- Farmers' feuds at https://economicconfidential.com/special-focus/economic-havocs-fulani-farmers-feuds/.

2. Alhassan Usman (2013): Herdsmen and Farmers Conflicts in North-Eastern Nigeria: Causes, Repercussions and Resolutions. Academic Journal of Interdisciplinary Studies vol 2 no 5.

3. CAUSES, EFFECTS AND RESOLUTION OF FARMERS-NOMADIC CATTLE HERDERS CONFLICT IN DELTA STATE, NIGERIA (PDF Download Available). Available from: https://www.researchgate.net/publication/264205109_CAUSES_EFFECTS_AND_RESOLUTION_OF_FAR MERS-NOMADIC_CATTLE_HERDERS_CONFLICT_IN_DELTA_STATE_NIGERIA [accessed Feb 18 2018].

4. Crisis Group interview, cattle breeders' association official, Kaduna, 18 September 2016.

5. Crisis Group interview, Miyetti Allah, cattle breeders association of Nigeria official, Abuja, 12 October 2016.

6. Crisis Group interview, senior police officer, Abuja, 8 June 2016.

7. Crisis Group interview, Yola, Adamawa state, 5 November 2016; "Boko Haram: We lost over 1 million cattle to insurgents - MACBAN", Daily Post, Abuja, 12 January 2017.

8. Crisis Group interviews, Nigeria Customs Service officer, Abuja, 9 June 2016; and member, Presidential Committee on Small Arms and Illegal Weapons, Abuja, 10 June 2016. In 2013, Nigerian military officials reported that Boko Haram insurgents had also received arms from Libya, following 2011 fall of Muammar Qadhafi regime. See Crisis Group Report, Curbing Violence in Nigeria (II), op. cit., p. 25.

9. Daily Trust, 17 February 2017. "1,135 people killed in Zamfara banditry in four years - NSCDC",

10. Herdsmen and Farmers Conflicts in North-Eastern Nigeria: Causes, Repercussions and Resolutions (PDF Download Available). Available from: https://www.researchgate.net/publication/272711427_Herdsmen_and_Farmers_Conflicts_in_NorthEastern_Nigeria_Causes_Repercussions_and_Resolutions [accēessed Feb 18 2018].

11. https://www.investopedia.com/terms/a/annuity.asp\#ixzz57qr3CKpN

12. https://www.naija.ng/814082-analysis-the-deadly-influx-of-the-fulani-herdsmen-in-nigeria.html\#814082.

13. https://www.naija.ng/814082-analysis-the-deadly-influx-of-the-fulani-herdsmen-in-nigeria.html\#814082.

14. Human capital theory by Simple Econonmist at http://simpleeconomist.com/human-capital-theory/

15. In March 2017, the humanitarian needs assessment organisation, ACAPS, reported that in 2016 alone, at least 2,069 people died in herder-related violence in just Benue and Kaduna states. Nigeria Farmer-Fulani Herder Violence in Benue, Kaduna and Plateau States, ACAPS, 21 March 2017.

16. International Crisis Group Report (2017) Herders against Farmers: Nigeria's expanding Deadly Conflict at https://www.crisisgroup.org/africa/west-africa/nigeria/252-herders-against-farmers-nigerias-expandingdeadly-conflict

17. Mohammed J. Kuna and Jibrin Ibrahim (eds.), Rural Banditry and Conflicts in Northern Nigeria, Centre for Democracy and Development (Abuja, 2015); and Olaniyan, Azeez and Yahaya, Aliyu, "Cows, Bandits, and Violent Conflicts: Understanding Cattle Rustling in Northern Nigeria", Africa Spectrum, vol. 51, no. 3 (2016), pp. 93-105. 
18. Natalie Wolchover 2011: What's the Dollar Value of a Human Life? https://www.livescience.com/15855dollar-human-life.html

19. Omawumi Eyekpimi (2016): History of Fulani Herdsmen and Farmers Clashes in Nigeria at www.herdsmen activities/History of Fulani Herdsmen and Farmers Clashes in Nigeria - Information Guide in Nigeria.html

20. Samuel Egwu, "The Political Economy of Rural Banditry in Contemporary Nigeria", Rural Banditry and Conflicts in Northern Nigeria, op. cit.2015.

21. Sulaiman and Ja`afar-Furo (2010): Economic Effects of Farmer-grazier Conflicts in Nigeria: A Case Study of Bauchi State.

22. This figure was provided by the president general of Nzor-Tiv Global Associates, Edward Ujege, at a public hearing convened by the House of Representatives in Abuja, 25 May 2016.

23. "The Economic Costs of Conflict: Evidence on Violence, Livelihoods and Resilience in Nigeria's Middle Belt", Mercy Corps, July 2015. 